\title{
Temporal and Spatial Variations of Trophic Status of a Small Lowland River
}

\author{
Ryszard Staniszewski ${ }^{1 *}$, Szymon Jusik ${ }^{1}$, Klaudia Borowiak ${ }^{\mathbf{1}}$, \\ Jerzy Bykowski², F. Hugh Dawson ${ }^{3}$ \\ ${ }^{1}$ Department of Ecology and Environmental Protection, Poznań University of Life Sciences \\ Piątkowska 94 Gate C, 60-649 Poznań, Poland \\ ${ }^{2}$ Institute of Land Improvement, Environmental Development and Geodesy, Poznań University of Life Sciences \\ Piątkowska 94 Gate E, 60-649 Poznań, Poland \\ ${ }^{3} \mathrm{CEH}$ Wallingford, Maclean Building, Crowmarsh Gifford, Wallingford, Oxfordshire OX10, 8BB UK
}

Received: 24 August 2017

Accepted: 29 October 2017

\begin{abstract}
The research area was situated in Kujawskie Lakeland (central Poland), where agricultural landscape, arable lands, and improved grasslands prevail. River water samples for physico-chemical analyses were collected in the years 1999, 2006, and 2010, together with macrophyte data. All studied sites were localised in the rural landscape with insignificant impact of shading on the structure of aquatic taxa. The analysis of temporal changes in the taxonomic composition of macrophytes was performed with linear indirect PCA ordination. Evaluation of the trophic status of the Noteć River was performed using different macrophyte metrics and the chemical index of trophy. There were not significant temporal shifts of the trophic level of studied sites evaluated both using macrophyte metrics and hydrochemical index, but particular physico-chemical parameters like total phosphorus, soluble reactive phosphates, conductivity, and $\mathrm{pH}$ reaction showed statistically significant temporal changes. Significant difference of trophic states between sites localised below lakes and the others was observed for all years.
\end{abstract}

Keywords: macrophytes, river trophy, mean trophic rank, chemical index of trophy, Noteć River

\section{Introduction}

The circulation of water and chemical components in rural landscapes has been seriously disrupted in recent decades as a result of growing civilization, including intensification of agriculture, the application of mineral fertilizers, chemical weed and pest control, high concentrations of livestock, and mistakes in agricultural

*e-mail: erstan@up.poznan.pl techniques. All of this has caused an increasing rate of eutrophication followed by changes in aquatic ecosystems.

Assessing the trophic status of rivers is less effective when only chemical data are used without any biological recognition of ecological conditions. Macrophytes, plant communities, diatoms, phytoplankton, and other biological indicators can be helpful in determining the trophic status and the quality of rivers as they can provide integrated values for periods of up to several months or even years depending on the group of organisms. Biological indicators are an integral part of modern 
determination of the trophic status of rivers in Europe. Moreover, macrophytes are perceived as a one the most valuable indicators and results based on aquatic plants reflect the trophic conditions of the water for a year or longer [1-5]. During field studies we used the macrophyte method, i.e., mean trophic rank [1] and hydrochemical index CIT [5].

The sites of the Noteć River in Kujawskie Lakeland (Figure 1) were situated in the agricultural landscape with the developed reclamation system, domination of arable lands, and improved grasslands [6-7]. Water quality in this watershed is affected by human activities, mostly agriculture and municipalities.

Two approaches - biological and hydrochemical were used to evaluate trophic conditions of the Noteć water. The main objectives of this paper were to assess the trophic status of the Noteć using different methods, evaluate the lake's impact on river trophy, and evaluate shifts of trophy in time.

\section{Materials and Methods}

\section{Study Sites}

Surveys were performed at 11 river Noteć sites (Fig. 1). Water samples were collected three times in the warm season of 1999, 2006, and 2010. All sites were situated in the rural landscape with insignificant impact of shading on the aquatic taxa structure. Spatial distribution was studied in two groups of sites located below lakes and others.

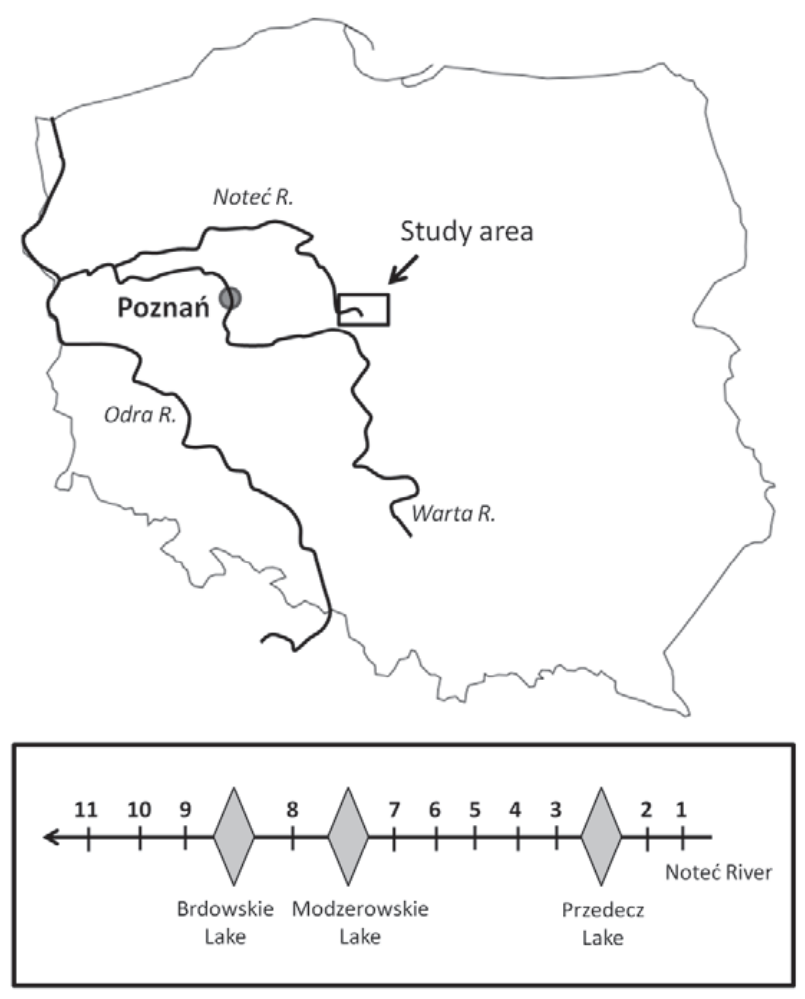

Fig. 1. Location of the study area and sites of the Noteć River.

\section{Macrophyte Sampling}

The studies of macrophytes were conducted three times: in 1999, 2006, and 2010. They were based on a quantitative and qualitative list of aquatic plants. The study sites were river sections with a length of $100 \mathrm{~m}$. Sites were surveyed twice during the fieldwork (upstream and downstream wading in the river bed) and the cover of all occurring taxa was recorded, including vascular plants, pteridophytes, bryophytes, and macroscopic algae. All plants growing permanently in the water were taken into account and cover of every taxa was determined according to the 9-point scale. Based on the botanical evaluation performed in the field, three bioindicators reflecting the trophic status of the studied sites were calculated:

- River macrophyte index (MIR) [8].

- Mean trophic rank (MTR) [1].

- River macrophyte nutrient index (RMNI) [9].

The results of MIR and MTR metrics ranged from 10 to 100 . Low values are related to hypertrophic and eutrophic conditions, while high values are related to oligotrophy. The RMNI index ranged from 1 to 10 and interpretation of results is opposite in comparison to MTR and MIR, thus low values indicate oligotrophy and high values indicate eutrophy and hypertrophy. Limit values of calculated bioindicators for each trophic level of water were accepted according to Jusik [10] and Willby et al. [9].

Additionally, other biological parameters were calculated: the number of species, total cover of macrophytes, and percentage of helophytes and hydrophytes.

\section{Chemical Sampling and Analysis}

The main physico-chemical parameters such as $\mathrm{pH}$ reaction and conductivity were monitored at all sites during fieldwork. Total phosphorus, soluble reactive phosphates (SRP), and nitrates were measured to assess the trophic conditions of water using chemical index of trophy (CIT) [5].

Water samples were collected from the middle of each site and filtered through a filter with a pore size of $0.45 \mu \mathrm{m}$. Trophic parameters, including soluble reactive phosphates (molybdenum blue method), total phosphorus (not filtered sample, molybdenum blue method after mineralisation), and nitrates (cadmium reduction method) were analysed using a spectrophotometer [11].

\section{Statistical Analyses}

Statistical analyses were conducted with Statistica 13 software [12]. The significance of differences between the three years $(1999,2006,2010)$ and between the river sites (1-11, Fig. 1) were analysed by one-way ANOVA. The analyses of environmental databases began by testing the distribution of water physical and chemical parameters in groups using the $\mathrm{W}$-value according to 
Shapiro-Wilk criteria. Brown-Forsyth and Levene's tests were used to assess the equality of variances.

Changes of physicochemical parameters and macrophyte metrics were analysed in the years 1999, 2006, and 2010, as well as differences resulting from the influence by the neighbourhood of lakes. One of the group of river sites (influenced by the presence of lakes) were sites 3, 8, and 9, which were located below lakes Przedecz, Modzerowskie, and Brdowskie. The second group (without influence of lakes) were all other sites (Fig. 1). Differences caused by the impact of lakes were analysed with the T-test for independent samples. The analyses were preceded by checking the normality of data distribution using the Shapiro-Wilk test.

The analysis of temporal changes in the taxonomic composition of macrophytes was performed with linear indirect PCA ordination, which is utilised in many scientific papers [13-16]. The choice of multivariate analysis was preceded by determination of the gradient width along the first canonical axis. DCA analysis revealed that the gradient was only $2.023 \mathrm{SD}$ and hence PCA ordination was applied.

\section{Results and Discussion}

Spatial changes of river water quality were surveyed recently in many river ecosystems and were mostly dealing with self purification processes, point and non-point sources of pollution, and the application of new techniques to evaluate water quality categories [26-29]. The impact of lakes on river ecosystems was less studied by environmentalists and was concentrated on water balance and river hydrology in relation to climate change, water chemistry, sediment transport, and chemistry [30-34]. This relationship, based on the energy of water discharge, is determining the geomorphology of the river channel and together with access to nutrients creates a habitat for aquatic fauna and flora [35-36].

Macrophytes are perceived as one of the best biological indicators for examining fresh water and are widely use in semi-natural and altered watercourses [2$3,37]$. Aquatic plants can describe water quality of a river for a longer period, such as hydrological year or season. They are not susceptible to incidental picks of concentrations of nutrients or heavy metals, thus their role in evaluating ecological status is important and they are a core indicator in many metrics used in the EU [2-4, 25, 36]. Many macrophyte taxa with different tolerances for nutrients were identified during studies. A total of 54 taxa of macrophytes - including 22 species of monocotyledons, 25 dicotyledonous, 2 pteridophytes, 2 mosses, and 3 algae - were identified. Rumex hydrolapathum was the most common species recorded at all sites, in all three years. The second most common was Lemna minor and Myosotis palustris, recorded at $76 \%$ of the sites and followed by Iris pseudacorus and Glyceria maxima, found at $70 \%$ of sites. The number of taxa at the study sites ranged from 12 to 31 with an average equal to 20 .

Trophic conditions were similar at most analysed sites, in all three years, and as indicated by bioindicators, they were between eutrophy and mesotrophy. The abiotic index CIT was characterised by a short gradient of results ranging from mesotrophic $(\mathrm{CIT}=7)$ to eutrophic conditions $(\mathrm{CIT}=10)$. The highest water trophy was observed in site 4 in 2006 and it was confirmed both by macrophyte indices and physicochemical parameters of water. Analysis of changes in the water trophic conditions between 1999-2006-2010 showed minor differences.

Statistically significant differences between biotic indices of trophic conditions (MIR, MTR, RMNI) and physicochemical parameters of water were not found. For instance, the highest Pearson linear correlation between the MIR index and total phosphorus was insignificant at $\mathrm{R}^{2}=0.14$. The lack of correlation resulted from similar abiotic conditions within surveyed sites, which resulted in a short gradient of the analysed factors.

Discrepancies were found between 1999, 2006, and 2010, and also between study sites (1-11) analysed using univariate ANOVA. Statistically significant differences were observed in the case of all physico-chemical water quality parameters $(\mathrm{p}<0.05)$ - especially between total phosphorus, SRP, nitrates, $\mathrm{pH}$, and conductivity (Table 1). The lowest mean values of total phosphorus and SRP were measured in $1999\left(0.14 \mathrm{mg} \mathrm{P} \cdot \mathrm{dm}^{-3}\right.$ and $0.29 \mathrm{mg} \mathrm{PO}_{4}^{3-\cdot} \mathrm{dm}^{-3}$ respectively). In 2006 a significant increase of both studied forms of phosphorus in water samples was found (mean values $0.75 \mathrm{mg} \mathrm{P} \cdot \mathrm{dm}^{-3}$ and $1.86 \mathrm{mg} \mathrm{PO}_{4}^{3-\cdot} \mathrm{dm}^{-3}$ ), and in 2010 a decrease in both forms was observed (mean equal to $0.48 \mathrm{mg} \mathrm{P} \cdot \mathrm{dm}^{-3}$ and $0.72 \mathrm{mg} \mathrm{PO}_{4}^{3-\cdot} \cdot \mathrm{dm}^{-3}$ ), but this change was not statistically significant. Another phenomenon was observed in the case of other physico-chemical parameters. The highest values of nitrates were found in 1999 (mean value $1.14 \mathrm{mg} \mathrm{N}-\mathrm{NO}_{3}^{-\cdot} \cdot \mathrm{dm}^{-3}$ ), while in 2006 a significant decrease of nitrate concentration was observed and was still present in $2010\left(0.11 \mathrm{mg} \mathrm{N}-\mathrm{NO}_{3}^{-} \cdot \mathrm{dm}^{-3}\right)$. Similarly, the highest values of conductivity were measured in 1999 (average equal to $1.072 \mathrm{mS} \cdot \mathrm{cm}^{-1}$ ), and a decrease was observed in 2006 and $2010\left(0.547 \mathrm{mS} \cdot \mathrm{cm}^{-1}\right.$ and $0.501 \mathrm{mS} \cdot \mathrm{cm}^{-1}$, respectively).

According to calculated macrophyte indices, only the total macrophyte cover was statistically different between years $(p<0.001$, Table 1). In 1999 and 2006 total cover was near $100 \%$, while in 2010 it was much smaller and reached only $45 \%$. At the same time there was no significant modification of river channel shadowing, which could support such a change in macrophyte cover. Macrophyte indices of trophy (MIR, MTR, RMNI) did not show significant changes of trophic values during studies ( $p>0.05$, Table 1). This indicates an improvement in trophic state (and improvement of water quality) between 2006 and 2010, which was especially visible in the case of such water quality parameters as total phosphorus, SRP, and conductivity. Average increase of MTR and MIR values was equal to 2.0 and RMNI 
a)

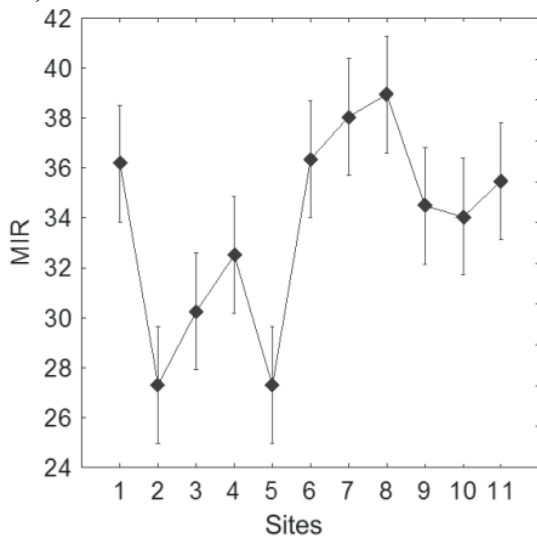

b)

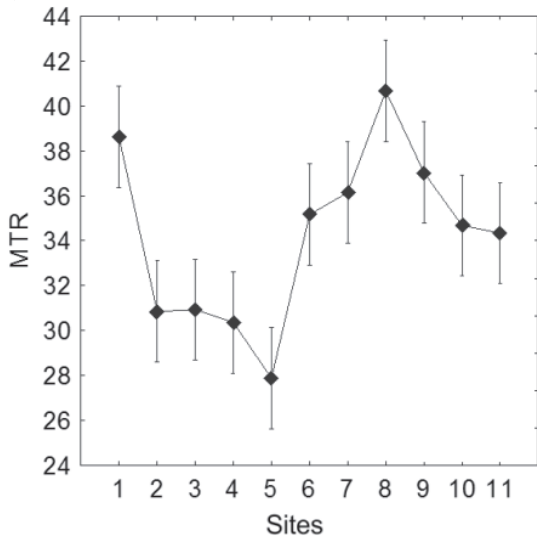

c)

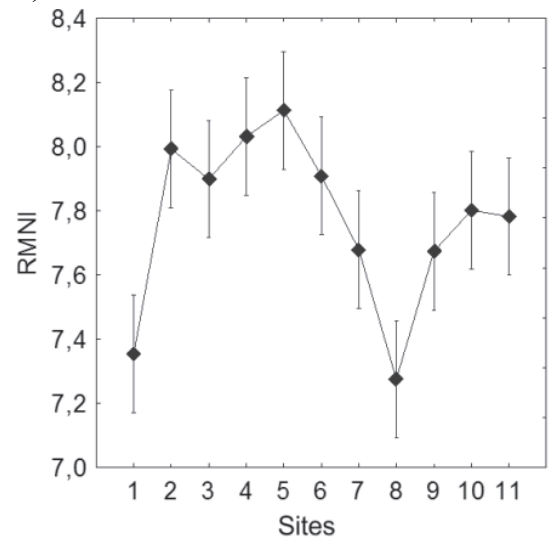

Fig. 2. Variability of macrophyte metrics among the river sites; plot indicates mean value, \pm standard error, and $\pm 1.96 \times$ standard error.

decreased of 0.2 (negatively correlated with MTR and MIR).

The second group of analyses was related to the differences between survey sites. In this part of studies, for all macrophyte indices (except total macrophyte cover) the statistically significant differences were found $(\mathrm{p}<0.001$, Table 1).

On the contrary, differences for all studied physicochemical parameters were not significant between sites. The highest values of total phosphorus and SRP were found in sites 2 and 4 (mean equal to $1.17 \mathrm{mg} \mathrm{P} \cdot \mathrm{dm}^{-3}$ and to $\left.2.82 \mathrm{mg} \mathrm{PO}_{4}^{3-\cdot} \mathrm{dm}^{-3}\right)$. In other surveyed sites values were smaller and rather uniform (mean equal to $0.30 \mathrm{mg} \mathrm{P} \cdot \mathrm{dm}^{-3}$ and $0.54 \mathrm{mg} \mathrm{PO}{ }_{4}^{3-\cdot} \mathrm{dm}^{-3}$ ) and differences were not statistically significant. In the case of nitrates, the highest values were measured in sites 1 and
2 (1.58 $\mathrm{mg} \mathrm{N}-\mathrm{NO}_{3}^{-} \cdot \mathrm{dm}^{-3}$ in average), while in other sites

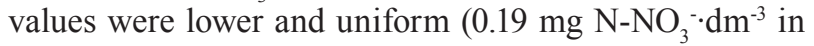
average) and not statistically significant. In the case of conductivity, a decrease in its mean value was observed from site $1\left(0.955 \mathrm{mS} \cdot \mathrm{cm}^{-1}\right)$ to sites $8-11\left(0.587 \mathrm{mS} \cdot \mathrm{cm}^{-1}\right)$.

All evaluated macrophyte parameters (except total cover) were statistically different between sites $(p<0.001$, Table 1). According to the number of taxa, sites 7 and 10 were diverse due to the high number of identified taxa (30 and 29, respectively). Other sites were characterised with significantly lower number of taxa, from 14 to 21 . High diversity was found for the presence of different ecological groups of macrophytes, and two clusters of sites could be distinguished. Sites 2-7 were characterised by domination of hydrophytes (mostly submerged plants and pleustophytes), which covered $60-80 \%$ of river site

Table 1. Assessing the significance of differences of analysed parameters between years and sites by one-way ANOVA.

\begin{tabular}{|c|c|c|c|c|}
\hline \multirow{2}{*}{ Analysed parameters } & \multicolumn{2}{|c|}{ Difference between years } & \multicolumn{2}{|c|}{ Difference between sites } \\
\cline { 2 - 5 } & $\mathrm{F}(2,30)$ & $\mathrm{p}$ & $\mathrm{F}(2,30)$ & $\mathrm{p}$ \\
\hline Total phosphorus & 3.696 & $* 0.037$ & 1.436 & 0.229 \\
\hline SRP & 3.685 & $* 0.037$ & 1.264 & 0.308 \\
\hline Nitrates & 4.353 & $* 0.022$ & 0.836 & 0.600 \\
\hline $\mathrm{pH}$ & 4.216 & $* 0.024$ & 0.720 & 0.698 \\
\hline Conductivity & 40.170 & $* * *<0.001$ & 0.403 & 0.931 \\
\hline CIT & 0.036 & 0.965 & 1.980 & 0.087 \\
\hline No. of species & 0.194 & 0.825 & 26.790 & $* * *<0.001$ \\
\hline Total cover & 9.132 & $* * *<0.001$ & 1.113 & 0.396 \\
\hline Percentage of helophytes & 0.523 & 0.598 & 6.014 & $* * *<0.001$ \\
\hline MIR & 0.719 & 0.495 & 12.479 & $* * *<0.001$ \\
\hline MTR & 0.796 & 0.461 & 12.807 & $* * *<0.001$ \\
\hline RMNI & 1.014 & 0.375 & 9.086 & $* * *<0.001$ \\
\hline
\end{tabular}

Significant differences: *, $\mathrm{p}<0.05 ; * *, \mathrm{p}<0.005 ; * * *, \mathrm{p}<0.001$ 
areas. In sites 1 and 8-10, the emerged plants (helophytes) were dominant and covered $60-95 \%$ of river site areas.

Trophic macrophyte indices also were strongly differentiated between river sites. Analysed indices (MIR, MTR, RMNI) showed similar results (Fig. 2) and showed significant increases in water trophy between site 1 and sites 2-5, and a decrease of water trophy from sites 5 to 8 , and subsequent increases between sites 8 and 9-11 (Fig. 2).

Statistically significant differences between sites located below the lakes $(3,8-9)$ and others (1-2, 4-7, 10-11) was observed only for the CIT index (T-test, $p=0.006)$. The average value of chemical index of trophy for sites affected by lakes was equal to 7.00, while in the case of other sites it was equal to 7.92 (Fig. 3). This indicates the role of lakes in limitation of river water trophy in sites below them. Such a phenomenon also was observed in earlier studies in different watersheds, which was related to processes of sedimentation and absorption occurring in lakes [17-19]. The rate of such a decrease of nutrient concentration below a lake can reach $24 \%$ in the case of phosphorus and even $40 \%$ of nitrogen as in Mielno Lake watershed [19]. Seasonal variations of trophic parameters can differ from several hundred percent for certain rivers (as in the Buyuk Melen and Kucuk Melen rivers in Turkey [20]) to slight changes in the Noteć in Poland $[5,7]$. Changes of macrophyte taxa structure were analysed using PCA, due to the small gradient of variability represented by first axis (only $2.023 \mathrm{SD}$ ). Two first axes describe respectively $23.6 \%$ and $19.1 \%$ of total variance of the sample (Fig. 4). There were no significant taxonomic changes in the analysed period of 1999-2006, and in most cases they were very minor and limited to the species cover. Most significant temporal changes were recorded at site number 2. Four species were not recorded in 2006, such as Berula erecta, Callitriche cophocarpa, Lemna minor, and Potamogeton crispus, and six new species were found: Alisma plantago-aquatica, Butomus umbellatus, Iris pseudacorus, Lemna gibba, Rorippa amphibia, and Spirodella polyrhiza. Seven species changed their contribution in the vegetation cover and only 3 species remained unchanged: Phragmites australis, Polygonum amphibium, and Sium latifolium.

Greater changes of taxonomic structure of macrophytes were observed between 2006 and 2010 (Fig. 4), which was correlated with the shift of total macrophyte cover, which in the years 1999 and 2006 was close to $100 \%$ and dropped to $45 \%$ (average) in 2010. Decline of the plant cover was related mostly to the group of hydrophytes, which are strongly connected to the aquatic environment, i.e., Ceratophyllum demersum, Cladophora sp., Elodea canadensis, and Hydrocharis morsus-ranae. The highest decline of plant cover in river sites was between 2006 and 2010 and was especially visible in the case of Ceratophyllum demersum, from $15.2 \%$ to $1.2 \%$ on average. Other taxa with significant fall of cover were Elodea canadensis (from 10.7\% to $6.9 \%$ ) and Cladophora sp. (from $2.8 \%$ to $0.5 \%$ ). Decline of the amount of specimens was found also for Acorus calamus (from $2.2 \%$ to $0.7 \%$ on average). Some taxa vanished and in the year 2010 plants like Butomus umbelatus, Chara globularis, Eupatorium cannabinum, Sium latifolium, and Vaucheria sp. were not observed in river sites. Moreover, in three sites surveyed in 2010, Equisetum fluviatile was identified, while in 2006 it was not observed. The highest changes in macrophyte cover in 2006 and 2010 were found in sites 7, 9, 10, and 3-6 (Fig. 4). In sites 7, 9, and 10 it was caused mostly by a decline of Hydrocharis morsus-ranae cover, and in sites 3-6 it was related to a decline of Ceratophyllum demersum, Elodea canadensis, and Cladophora sp., and the disappearance of Chara globularis and Vaucheria sp. It was also found that sites situated next to each other have similar direction of shifts in macrophyte structure between years, and this was especially visible for sites 3-5 (Figs 1 and 4).

Changes of macrophyte structure were observed also by other authors. It was often related to differences in flow velocity between stands, patterns of macrophyte stands, year season, presence of nutrients, sediment depth, and composition and especially fine sediment can play important roles in rivers, taking part in nutrients and metals storage and thus affecting aquatic plants [21-22]. The impact of lakes and ponds can be observed as a limitation in nutrient load in waters below reservoirs. Such a process can change structure macrophyte taxa as in the case of pre-dam and dam waters located on the small lowland river Wyżnica [23]. Reduction of nutrient load in pre-dam caused an increase in the number of taxa in dam waters and in one year even the appearance of charophytes, which are characteristic for clean and mesotrophic waters. The role of water reservoirs

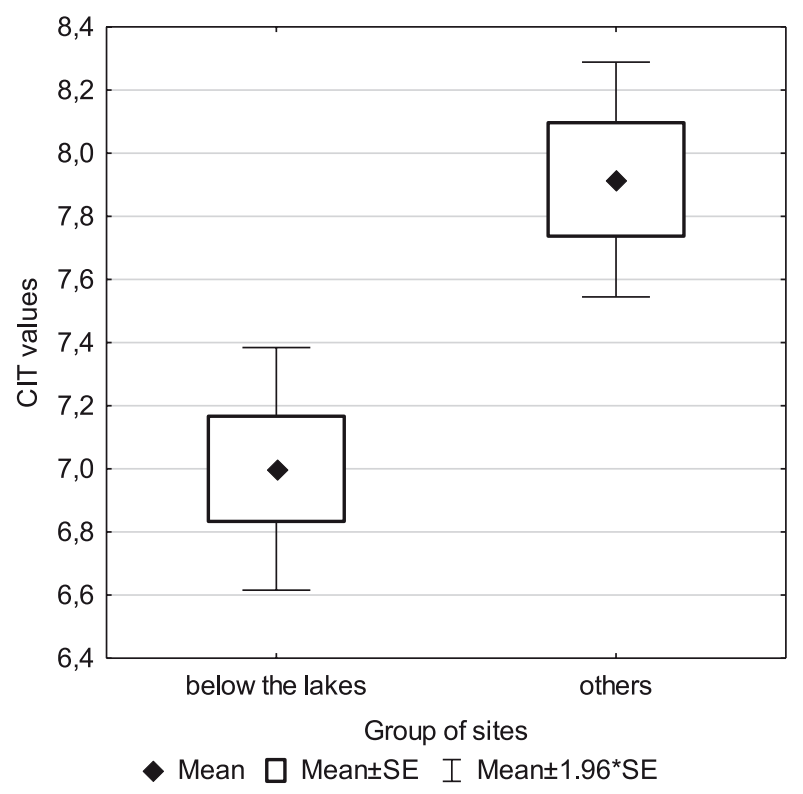

Fig. 3. Boxplot with whiskers showing the variability of basic statistics of CIT values between two groups of sites: located below the lakes $(3,8-9)$ and others $(1-2,4-7,10-11)$. 

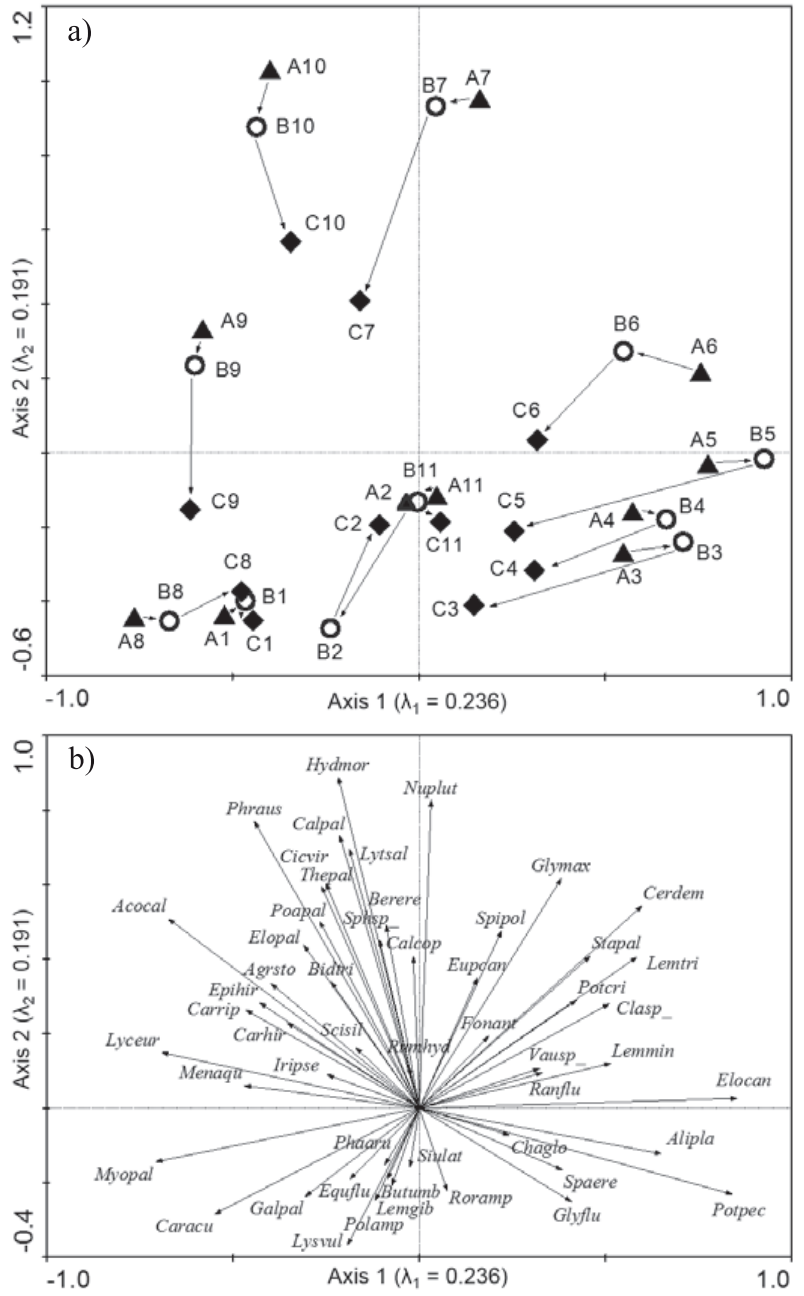

Fig. 4. PCA ordination diagram of changes of the taxonomic structure of macrophytes in 1999, 2006, and 2010.

a) scatter plots - sites: A1-A11 (triangles) - sites studied in 1999, B1-B11 (circles) - the same sites studied in 2006, C1-C11 (diamonds) - the same sites studied in 2010; b) scatter plots species: Acocal - Acorus calamus, Agrsto - Agrostis stolonifera, Alipla - Alisma plantago aquatica, Berere - Berula erecta, Bidtri-Bidens tripartita, Butumb - Butomus umbelatus, Calcop - Callitriche cophocarpa, Calpal - Caltha palustris, Caracu - Carex acuta, Carhir - Carex hirta, Carrip - Carex riparia, Cerdem-Ceratophyllum demersum, Chaglo-Chara globularis, Cicvir - Cicuta virosa, Clasp_ - Cladophora sp., Elepal Eleocharis palustris, Elocan - Elodea canadensis, Epihir Epilobium hirsutum, Equflu - Equisetum fluviatile, Eupcan - Eupatorium cannabinum, Fonant - Fontinalis antipyretica, Galpal - Galium palustre, Glyflu - Glyceria fluitans, Glymax Glyceria maxima, Hydmor - Hydrocharis morsus-ranae, Iripse - Iris pseudoacorus, Lemgib - Lemna gibba, Lemmin - Lemna minor, Lemtri - Lemna trisulca, Lyceur - Lycopus europaeus, Lysvul - Lysimachia vulgaris, Lytsal - Lythrum salicaria, Menaqu - Mentha aquatica, Myopal - Myosotis palustris, Nuplut - Nuphar lutea, Phaaru - Phalaris arundinacea, Phraus - Phragmites australis, Poapal - Poa palustris, Polamp Polygonum amphibium, Potcri - Potamogeton crispus, PotpecPotamogeton pectinatus, Ranflu - Ranunculus fluitans, Roramp - Rorippa amphibia, Rumhyd - Rumex hydrolapathum, Scisil Scirpus silvaticus, Siulat - Sium latifolium, Spaere-Sparganium erectum, Sphsp_- Sphagnum sp., Spipol - Spirodela polyrhiza, Stapal - Stachys palustris, Thepal - Thelypteris palustris, Vausp__ Vaucheria sp. in shaping macrophyte structure can be limited by several factors, such as intensive maintenance work in watercourses [24], point sources of pollution [25], and others.

\section{Conclusions}

1) Evaluating the trophic status of the Noteć using different macrophyte metrics indicated a higher trophic level than using the chemical index of trophy.

2) Insignificant differences of results of water trophy among macrophyte metrics were found. In the case of mean trophic rank, more than half of sites were classified as eutrophic, and using RMNI, 90\% of sites were eutrophic.

3) There were no significant temporal shifts of the trophic level of studied sites evaluated both using macrophyte metrics and hydrochemical index, but particular physico-chemical parameters showed statistically significant temporal changes, such as total phosphorus, soluble reactive phosphates, conductivity, and $\mathrm{pH}$ reaction.

4) Statistically significant impact of the lake presence on chemical index of trophy was observed, and sites located directly below lakes had lower trophic levels.

\section{Acknowledgements}

Studies were financed by the State Committee for Scientific Research (project Nos. KBN 6 P04G 02519 and KBN 2 P06S 019 27).

\section{Conflict of Interest}

The authors declare no conflict of interest.

\section{References}

1. DAWSON F.H., NEWMAN J.R., GRAVELLE M.J., ROUEN, K.J., HENVILLE P. Assessment of the Trophic Status of Rivers using Macrophytes: Evaluation of the Mean Trophic Rank. R \& D Technical Report E39. Environment Agency of England and Wales, 1, 1999.

2. SZOSZKIEWICZ K., KAROLEWICZ K., ŁAWNICZAK A., DAWSON F.H. An assessment of the MTR aquatic plant bioindication system for determining the trophic status of Polish rivers. Polish Journal of Environmental Studies 11, 421, 2002.

3. STANISZEWSKI R., SZOSZKIEWICZ K., ZBIERSKA J., LEŚNY J., JUSIK S., CLARKE R.T. Assessment of sources of uncertainty in macrophyte surveys and the consequences for river classification. Hydrobiologia 566, 235, 2006. 
4. WIEGLEB G., GEBLER D., VAN DE WEYER K., BIRK S. Comparative test of ecological assessment methods of lowland streams based on long-term monitoring data of macrophytes. Science of the Total Environment 541, 1269, 2016.

5. STANISZEWSKI R. Estimation of river trophy in Kujawskie Lakeland using Mean Trophic Rank and Chemical Index of Trophy. Rocz. AR Pozn. 334 (4), 139, 2001.

6. STANISZEWSKI R., SZOSZKIEWICZ J. Changes in the quality of water in Brdowskie Lake in the years in 1997-2006. Journal of Elementology 15 (4), 705, 2010.

7. MESSYASZ B., STANISZEWSKI R., JUSIK, S. Algae assemblages and dominant macrophytes in small lowland rivers of Poland in relation to water quality and hydromorphology. Fresenius Environmental Bulletin 23 (2a), 581, 2014.

8. SZOSZKIEWICZ K., ZBIERSKA J., JUSIK S., ZGOŁA T. Macrophyte Method for River Assessment. A methodological manual on the assessment and classification of the ecological status of flowing waters based on aquatic plants (in Polish). Bogucki Wydawnictwo Naukowe, Poznań, 32, 2010.

9. WILlBY N., PITT J.-A., PHILliPS G. The ecological classification of UK rivers using aquatic macrophytes. UK Environment Agency Science Reports. Project SC010080 /SR1. Environmental Agency, Bristol, 53, 2009.

10. JUSIK S. Guide to the identification of aquatic bryophytes for assessing the ecological status of surface waters in Poland (in Polish). Chief Inspectorate for Environmental Protection. Warszawa, 37, 2012.

11. HACH Company/Hach Lange GmbH. Water Analysis Guide, 60, 2013.

12. DELL INC. Dell Statistica (data analysis software system), version 13. software.dell.com, 2016.

13. STEVENS M.H.H., CUMMINS K.W. Effects of Long-Term Disturbance on Riparian Vegetation and In-Stream Characteristics. Journal of Freshwater Ecology 14 (1), 1, 1999.

14. TANG T., QUA X., LIA D., LIUA R., XIEA Z., CAIA Q. Benthic Algae of the Xiangxi River, China. Journal of Freshwater Ecology, 19 (4), 597, 2004.

15. SZOSZKIEWICZ K., KAYZER D., STANISZEWSKI R., DAWSON F.H. Measures of central tendency of aquatic habitat parameters: application to river macrophyte communities. Polish Journal of Ecology 58 (4), 693, 2010.

16. TER BRAAK C.J.F., ŠMILAUER P. CANOCO Reference manual and CanoDraw for Windows User's Guide: Software for Canonical Community Ordination (version 4.5). Microcomputer Power Ithaca, USA, 2002.

17. HEATHWAITE A.L. Nitrogen cycling in surface waters and lakes. In: Burt T.P., Heathwaite A.L., Trudgill S.T. (Eds). Nitrate: processes, patterns and management. John Wiley and Sons Ltd. Chichester, 99, 1993.
18. STANISZEWSKI R., SZOSZKIEWICZ J. Threats of freshwaters in Southern Kujawy on an example of selected lakes and watercourses (in Polish). Kształtowanie środowiska - zagrożenia i monitoring. Zesz. Probl. Post. Nauk Roln., 505, 407, 2005.

19. LOSSOW K., GAWROŃSKA H., ŁOPATA M., TEODOROWICZ M. Role of lakes in phosphorus and nitrogen transfer in the river-lake system of the Marózka and the upper Łyna rivers. Limnological Review 6, 171, 2006.

20. OKATAN A., YILMAZ M., USTA A., YILMAZ, S. Evaluating seasonal variations of water quality variables in rivers within the Duzce watershed, Turkey. Fresenius Environmental Bulletin 19 (10), 2138, 2010.

21. COTTON J.A., WHARTON G., BASS J.A.B., HEPPEL C.M., WOTTON R.S. The effects of seasonal changes to in-stream vegetation cover on patterns of flow and accumulation of sediments. Geomorphology 77, 320, 2006.

22. HALEY M.A. The impact of stream support on the hydrology and macrophytes of the upper Bristol Avon. Bioscience Horizons 2 (1), 44, 2009.

23. TARKOWSKA-KUKURYK M. Effect of phosphorus loadings on macrophytes structure and trophic state of dam reservoir on a small lowland river (eastern Poland). Archives of Environmental Protection 39 (3), 33, 2013.

24. HACHOE J., BONDAR-NOWAKOWSKA E. An Assessment of the Ecological Status of Diverse Watercourses of Lower Silesia, Poland. Polish Journal of Environmental Studies 21, 75, 2012.

25. HAURY J., PELTRE M.-C., TRÉMOLIÈRES M., BARBE J., THIÉBAUT G., BERNEZ I., DANIEL H., CHATENET P., HAAN-ARCHIPOF G., MULLER S., DUTARTRE A., LAPLACE-TREYTURE C., CAZAUBON A., LAMBERT-SERVIEN E. A new method to assess water trophy and organic pollution the Macrophytes Biological Index for Rivers (IBMR): its application to different types of river and pollution, Hydrobiologia 570, 1538, 2006.

26. NĘDZAREK A., BONISŁAWSKA M., TÓRZ A., GAJEK A., SOCHA M., HARASIMIUK F.B. Water quality in the central reach of the Ina River (Western Pomerania, Poland). Polish Journal of Environmental Studies 24 (1), 20, 2015.

27. HUA A.K., KUSIN F.M., PRAVEENA S.M. Spatial variation assessment of river water quality using environmetric techniques. Polish Journal of Environmental Studies 25 (6), 2411, 2016.

28. LEŠČEŠEN I., PANTELIĆ M., DOLINAJ D., STOJANOVIĆ V., MILOŠEVIĆ D. Statistical analysis of water quality parameters of the Drina River (West Serbia), 2004-11. Polish Journal of Environmental Studies 24 (2), 555, 2015.

29. XU W., DONG Z., HAO Z., LI D., REN L. River health evaluation based on the fuzyy matter-element extension assessment model. Polish Journal of Environmental Studies 26 (3), 1353, 2017. 
30. STANISZEWSKI R. Heavy metals in waters and sediments of rivers affected by brown coal mine waters. Polish Journal of Environmental Studies 23 (6), 2217, 2014.

31. UNCUMUSAOGLU A.A., AKKAN T. Assessment of stream water quality using multivariate statistical techniques. Polish Journal of Environmental Studies 26 (4), 1715, 2017.

32. HUZIY O., SUSHAMA L. Lake-river and lakeatmosphere interactions in a changing climate over Northeast Canada. Climate Dynamics 48 (9-10), 3227, 2017.

33. ZENGXIN Z., XI CH., CHONG-YU X., YANG CH., HARDY J., ZHONGHUA S. Examining the influence of river-lake interaction on the drought and water resources in the Poyang Lake basin. Journal of Hydrology 522, 510, 2015.

34. SZYCZEWSKI P., SIEPAK J., NIEDZIELSKI P., SOBCZYŃSKI T. Research of heavy metals in Poland. Polish Journal of Environmental Studies $\mathbf{1 8}$ (5), 755, 2009.
35. GUISHAN Y., QI Z., RONGRONG W., XIJUN L., XIA J., LING L., HUICHAO D., GUANGCHUN L., JIANCHI CH., YONGJUN L. Lake hydrology, water quality and ecology impacts of altered river-lake interactions: advances in research on the middle Yangtze river. Hydrology Research 47, 1, 2016.

36. SZOSZKIEWICZ K., CIECIERSKA H. KOLADA A., SCHNEIDER S.C., SZWABIŃSKA M., RUSZCZYŃSKA J. Parameters structuring macrophytes communities in rivers and lakes results from a case study in North-Central Poland. Knowledge and Management of Aquatic Ecosystems 415 (08), 2014. [Access: August 2 $2^{\text {nd }}, 2017$, https:// www.kmae-journal.org/articles/kmae/abs/2014/04/ kmae140016/kmae140016.html]

37. STANISZEWSKI R., JUSIK S. Impact of mine waters discharge from open-pit lignite mine on river water quality. Rocznik Ochrona Środowiska 15 (3), 2652, 2013. 